\title{
Enhancing Students' Soft Skills Competence and Grade Through Experiential Learning in the Feed Industry Management Subject
}

\author{
Khali $^{1}$ \\ $\left\{\right.$ khalil@ansci.unand.ac.id $\left.{ }^{1}\right\}$ \\ Department of Animal Nutrition and Feed Technology, Faculty of Animal Science, Universitas \\ Andalas, Padang, Indonesia
}

\begin{abstract}
The present research was carried out to study the beneficial effects of the application of the Experiential Learning (EL) in the form of the assignment of scientific paper on the improvement of soft skills and achievements of student grades. The study involved 80 students enrolled Feed Industry Management subject located in Limau Manis (PDG) dan Payakumbuh (PYK) Campus. They were divided into three parallel classes: P03PDG (32 students), P01PYK (31) and P02PYK (17). The students were offered a structured assignment, starting with an explanation of the material, measuring physical properties of feed in the laboratory, calculating and processing of data, writing and submission of draft and final scientific paper. Students were closely mentored and offered feedback at each stage of the task to encourage the students to do so with an honest, disciplined, obedient and earnest. Parameters observed included soft skills (honesty, discipline, obedience, earnest) and achievement grades (mid exam, final grades). The results showed that the group of students P01PYK and P02PY shows better honesty, discipline, obedience and sincerity than that in the class P03PDG. Assignment might promote the improvement of soft skills of students, but there was no significant effect on achievement mid exam scores. It might be concluded that that learning through assignments preceded by field experiences in the laboratory has a positive effect on student soft skills but the application of this EL model has not been able significantly to improve student achievement.
\end{abstract}

Keywords: Learning process, Experential learning,Soft skills.

\section{Introduction}

The learning process in the PTK 257 Feed Industry Management subject is still emphasized on theoretical materials in the classroom. Since the last three years, subject credit was reduced from $3[3(2-1)]$ to 2 [2(2-0)], which eliminated practical objects or laboratory works. Students enrolled this subject are only equipped with theories in feed production processing and management, started from procurement and handling of raw materials, production processes, product handling, utility management, production management, quality control and quality assurance. Students are sometimes invited to visit animal feed companies located outside of the province. The field study, however, cannot be carried out routinely, due to various limiting reasons, such as high travel costs, tight lecture schedules in the campus, and limited time of lecturers. Consequently, students are not able to understand the course material 
optimally, resulting in poor average test scores of below 50. The students based in main campus of Limau Manis Padang tended to have lower exam grade than that in the Campus II Payakumbuh presumably due to poor learning behavior.

Lecturers tend to give over grade, far above the real abilities of students. Despite having academic high grade and attending some retraining programs, it is still difficult for the graduates in animal production to find jobs or to create private business. The problem of unemployed graduates has been widely claimed as a major causing factor for low preference of young teenager to study in animal production. One of the major causes identified is the lack of soft skills among graduates, which makes them unable to compete in the current competitive job market. Soft skill is the competence that is needed in the workplace [1]. Soft skills are behaviors that must be internalized as a natural aspect of a person's repertoire of social skills and character attributes. Some of areas of soft skills which seem to be lacking include critical thinking, communications, presentations, leadership, teamwork, interpersonal skills, management skills, time management and problems solving skills [2]. There are growing demands for graduates to be equipped with more than just an academic degree. Graduates are weak in using their classroom knowledge when confronted with new or slightly different situations.

Feed Industry Management subject provide students with the various knowledge and skills to manage the business of production of feed. Feed processing company for poultry, fish and pet animals continues to grow in line with the increasing demand for livestock, fish products and pet animals in Indonesia. Multi-national leading feed companies such as PT. Charoen Pokphand Indonesia, P.T. Japfa Comfeed, PT. Cargill Indonesia, PT. Central Proteina, PT. Cheil Jedang Feed and PT. Gold Coin Indonesia continues to increase their production capacity and expand the construction of new factories in various regions of the country. Various businesses opportunities related to poultry feed, fish feed and pet food in the form of raw material production business, trade and services have also expanded to remote areas, which are also attractive for graduates to become business objects. The absence of work practical objects, the lack of supporting facilities on campus and the obstruction of field study activities need to be overcome by implementing Experiential Learning (EL) programs. Katula and Threnhauser [3] label EL mode to refer to the learning "process that takes place beyond the traditional classroom and that enhances the personal and intellectual growth of the student.

The purpose of this research was to study the beneficial effects of applying the EL learning model to build honesty, discipline, obedience, and seriousness and to achieve a maximal final grades taking the subject of PTK 267. Feed Industry Management. It was hypothesized that the students would be able to achieve better grades, if they are led to behave in an honest, disciplined, obedient, and earnestly as they have opportunity to explore the experience in the laboratory work prior to theoretical explanation.

\section{Methodology}

\subsection{Experiential Learning Model}

The current learning system applied in the subject is known as student center learning (SCL) model. Lecturers first elaborate theories on certain selected topic, followed by small group discussions in different subtopic to broaden and deepen the subject matter. The SCL model however has proven to be unable to optimally exploit students' abilities and curiosity, 
due to limited face-to-face time and reference material. Even though the most students might achieve a high standard grade (> 80), but the high grade obtained are not reflected in the abilities that should be mastered by students. This can be observed from the performance of the students during group discussions that are still not straightforward and have limited mastery of the material.

One of the learning model that can be applied is the Experiential Learning model (EL Model), as has been proposed to be adopted in the curriculum of animal production science [4]. This learning model is widely applied to vocational education (vocational education) [5]. According to Conrad and Hedin [6] experiential learning can be defined as "educational programs taking place outside the traditional classroom where students are in significant new roles with tasks with real consequences, and where the emphasis is on doing with associated reflection". This learning system provides opportunities for students to gain experience from objects that will be studied prior to accepting theoretical description in the classroom. This experiential learning model is described in the form of the Kolb cycle (Kolb's Experiential Learning Cycle model) [7] (Figure 1).

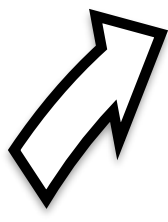

AC

Abstract Conceptulisation

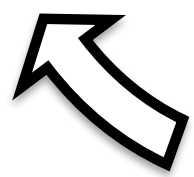

$\mathrm{AE}$

Active Experimentation

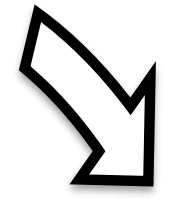

CE

Concertrate Experience

RO

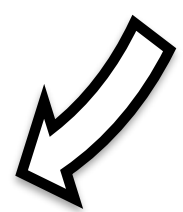

Reflective Observation

Fig. 1. Kolb's Experiential Learning Cycle [7]

\subsection{Implementation of EL Model}

The implementation of the EL model in this study was designed in the form of assignment. The students enrolled in the "Feed Industry Management " subject are assigned to compile scientific paper related to aspects of raw material management in the feed industry. The activity begins by providing an explanation of the objectives, material and scope of tasks, collecting data and information, drafting scientific works, discussing improvements to the draft, and ending with the preparation and submission of final scientific paper. The assignment begins by explaining the objectives, material and scopes of tasks, collecting data and information, drafting 
scientific works, discussing improvements to the draft, and ending with the preparation and submission of final scientific papers.

The students carried out assignment individually. They were guided and informed gradually for better understand, so that they might be able to do the job according to the procedures. At first, students collect data by measuring of four physical properties of various types of feed ingredients in the laboratory. Data were then analyzed and discussed in relation with the efficiency of handling, processing and storing in bulk system. This method combines the Case Study (CS) and Project Based Learning (PjBL).

\subsection{Research procedures}

The study was conducted for about three months, from mid-January to March 2019, which involved 80 students enrolled in courses Feed Industry Management in the even semester of 2018/2019. Students were divided into three groups in different parallel classes. Group A was class parallel class 03 (P03PDG) located at the Padang Limau Manis Campus with a total of 31 students. Group B and Group C were parallel classes 01 (P01PYK) and 02 (P02PYK) located at Campus II Payakumbuh with the total student number each of 31 and 17, respectively. Students in all groups were in the first week informed in detail about the objectives, scope, time schedule and procedures of assignment. At week 2, students measured physical properties of 15 different kinds and particle sizes of feedstuffs in laboratory for 3-4 days. Individual data was recorded in special forms, calculated and analyzed statistically. Final data was then sent to the lecturer in accordance with a predetermined schedule. The collected data was evaluated to determine the accuracy of the method of calculation, analysis and the results.

The results of data evaluation were explained and discussed with the students in week 3 . Students are guided to make correction and their data, to prepare various forms of diagrams or figures, and to draft scientific paper. Students were given time for one week to prepare the scientific paper, and then sent to the lecturer. Each paper draft was read though for evaluated on the following aspects: writing format; plagiarism; relevance between background, objectives and conclusions; procedure description, data presentation, explanation of results and references used. The evaluation summaries were explained to students in the following week. Students had for one week to make improvements in accordance with the findings and suggestions. Final papers were submitted to the lecturer according to the predetermined time schedule.

\subsection{Parameters and Assessment Methods}

The parameters observed in this study are soft skills and achievement values. There are for attributes softs kills observed, namely: honesty, obedience, discipline, and seriousness. Soft skills assessment was done by observing or referring to the attendance data, adherence to follow a schedule, and quality of scientific papers (Table 1). The achievement of the final grade was calculated from the average score of midterms exam and the score of the assignment with the same proportion. Parameter ratings scientific papers (60-100) covering the following four aspects, namely: relevance (between background with the objectives, procedures, results, discussion and conclusion), the scope and variety of data presentation, and writing technique.

Table 1. Reference for assessment of soft skills

\begin{tabular}{lclc}
\hline No & $\begin{array}{c}\text { Soft skill } \\
\text { attributes }\end{array}$ & \multicolumn{1}{c}{ Parameters } & Reference materials \\
\hline 1 & Honesty & $\begin{array}{l}\text { The level of plagiarism of data and } \\
\text { scientific papers }\end{array}$ & Data, scientific papers \\
\hline
\end{tabular}




\begin{tabular}{llll}
\hline 2 Discipline & $\begin{array}{l}\text { Presence, completeness equipment, Attendance and time data } \\
\text { technical writing, timeliness of data } \\
\text { submission and scientific papers }\end{array}$ \\
& $\begin{array}{l}\text { Presence, timeliness of data submission } \\
\text { and scientific papers, writing techniques. }\end{array}$ & $\begin{array}{l}\text { Recap schedule of data } \\
\text { and paper submission } \\
\text { data quality, scientific } \\
\text { papers }\end{array}$ \\
4 Seriousness & $\begin{array}{l}\text { Data presentation techniques, writing Data and scientific } \\
\text { techniques, variations in the presentation } \\
\text { of data }\end{array}$ & $\begin{array}{l}\text { papers, data and paper } \\
\text { quality }\end{array}$ \\
\hline
\end{tabular}

\section{Results and Discussion}

One of the most remarkable models on the field of experiential learning developed by Kolb's (1984) who urged that the process whereby knowledge is created through the transformation of experience experiential learning theory (ELT). Knowledge arises from the combination of the individual's reflecting, grasping and transforming new and prior experiences. According to Kolb and Kolb (2005) learning results from synergistic transactions between the learner and the environment. Thus, learning is a holistic process of adaption to contextual changes, trends, and circumstances that shape individual experience. The EM model has been implemented and shows positive results for improving achievement of learning outcomes in course PTK 267. Feed Quality Control (Khalil, 2017). Besides increasing the achievement of learning outcomes, the application of the EL model in the subjects PTK 257. The Feed Industry Management is expected to also be able to develop soft skills. There are at least seven attributes of soft skills that are related with critical thinking, management and interpersonal skills, namely honest, disciplined, obedient, serious, hard work, creative and innovative.

\subsection{Effect of assignment on the student soft skills}

Table 2 presents the lecture attendance data as well as obedience and discipline students to the performance of assignment following the implementation schedule. The attendance rate at the total seven lecture meetings ranged from $87-95 \%$. This figure shows that most students have attended the lectures in accordance with the minimum requirements for the exam (80\%). As shown in Table 2, the majority of students (82-100\%) was present and follows an explanation of assignment. All students in the Group A (P03PDG) participated in the explanation of the assignment, but only 20 or $62.5 \%$ were present and active in the laboratory. The absence in the lab was due to several reasons, such as lack of accessory equipment, late coming and hope that it will also be allowed and forgiven. This shows the lack of discipline and obedience was found seriously by the student from the P03PDG class.

Table 2. Response of students to the assignment of the subject of PTK 257. Feed Industry Management in the even semester year 2018/2019

\begin{tabular}{clccc}
\hline \multirow{2}{*}{ No } & \multirow{2}{*}{ Parameters } & \multicolumn{3}{c}{ Parallel Class: } \\
\cline { 3 - 5 } & & P03PDG & P01PYK & P02PYK \\
\hline 1 & Number of enrolled students (student) & 32 & 31 & 17 \\
2 & Rate of course attendance (\%) & 88.9 & 95.4 & 86.6 \\
\hline
\end{tabular}




\begin{tabular}{|c|c|c|c|c|}
\hline 3 & Implementation of assignment: & & & \\
\hline 3.1 & $\begin{array}{l}\text { Number of students present at the explanation of } \\
\text { the assignment material (student)(\%) }\end{array}$ & $\begin{array}{c}32 \\
(100.0)\end{array}$ & $\begin{array}{c}29 \\
(90.6)\end{array}$ & $\begin{array}{c}14 \\
(82.4)\end{array}$ \\
\hline 3.2 & $\begin{array}{l}\text { The number of students who carry out assignment } \\
\text { in the laboratory (student) (\%) }\end{array}$ & $\begin{array}{c}20 \\
(62.5)\end{array}$ & $\begin{array}{c}31 \\
(100.0)\end{array}$ & $\begin{array}{c}17 \\
(100.0)\end{array}$ \\
\hline 3.3 & $\begin{array}{l}\text { The number of students submitting data (student) } \\
(\%)\end{array}$ & $\begin{array}{c}22 \\
(68.8)\end{array}$ & $\begin{array}{c}29 \\
(90.6)\end{array}$ & $\begin{array}{c}17 \\
(100.0)\end{array}$ \\
\hline 3.4 & $\begin{array}{l}\text { The number of students who submit revised data } \\
\text { (student) }(\%)\end{array}$ & $\begin{array}{c}20 \\
(62.5)\end{array}$ & $\begin{array}{c}29 \\
(90.6)\end{array}$ & $\begin{array}{c}17 \\
(100.0)\end{array}$ \\
\hline 3.5 & $\begin{array}{l}\text { The number of students who submitted draft } \\
\text { scientific papers (student) \%) }\end{array}$ & $\begin{array}{c}14 \\
(43.8)\end{array}$ & $\begin{array}{c}29 \\
(90.6)\end{array}$ & $\begin{array}{c}17 \\
(100.0)\end{array}$ \\
\hline 3.6 & $\begin{array}{l}\text { The number of students who submit revised } \\
\text { scientific paper (student) }(\%)\end{array}$ & $\begin{array}{c}16 \\
(50.0)\end{array}$ & $\begin{array}{c}29 \\
(90.6)\end{array}$ & $\begin{array}{c}17 \\
(100.0)\end{array}$ \\
\hline 4 & Mean grade: & & & \\
\hline 4.1 & Mean grade point of midterm exam for class & 35.4 & 49.9 & 34.8 \\
\hline 4.2 & $\begin{array}{l}\text { Mean grade point of midterm exam for students } \\
\text { by assignment }\end{array}$ & 39.1 & 50.9 & 34.8 \\
\hline 4.3 & Mean grade point of assignment & 69.1 & 79.0 & 77.4 \\
\hline 4.4 & Mean final grade & 54.1 & 65.0 & 56.1 \\
\hline
\end{tabular}

Furthermore, discipline and compliance of student attending course at Limau Manis campus (P03PDG) in obeying the deadline of data and paper submission was found very poor with the percentage ranged between 44 and $69 \%$. There were also students from parallel P03PDG who did lie, which was identified from the number of students submitted data (22 students) more than the number of students enrolled and active in the laboratory (20 students). Lying attitude, lack of discipline and obedience of students from class P03PDG also was identified in the draft of scientific papers. Most of them did not follow the writing format, regarding page number, line spaces, writing structure as listed in the manual description.

Table 3 presents assessment summary of data and draft of scientific papers summitted by the students. The common weaknesses found in the scientific paper drafts were: the majority of the content was plagiarism, backgrounds are less relevant to the purpose and conclusions, description of the procedure is less systematic and unclear, poor variations of data presentation, the data presented was less relevant to the explanation, and limited relevant references. Data analysis and drafting of the paper were not seriously done, as seen from the poor display of paragraphs, tables and diagrams. Calculation and data analysis were mostly still done manually, while most of the content of scientific work is plagiarism, starting from introduction to conclusion, especially from the group of students from the class P03PDG. This plagiarism could be easily identified from the formatting, fonts and paragraphs, sentence structure, and the relation between sentences and between sections. Besides the lack of experience in writing, the students did not fully understand the job description, especially the working procedures and data analysis. In general, it shows that students are not accustomed to working hard and seriously to achieve the best results.

Table 3. List of evaluation results of scientific paper drafts that need improvement

\begin{tabular}{llll}
\hline No & Point & Subpoints & Remark \\
\hline
\end{tabular}




\begin{tabular}{|c|c|c|c|}
\hline 1 & Writing Format & $\begin{array}{l}\text { - Writing: not in accordance with the } \\
\text { provisions (of the page, spacing), } \\
\text { grammar, writing letters } \\
\text { - Pictures: incomplete, unclear, no identity }\end{array}$ & \\
\hline 2 & $\begin{array}{l}\text { Data } \\
\text { management } \\
\text { and submission }\end{array}$ & $\begin{array}{l}\text { - The number of students who submit the } \\
\text { data exceeds the number of registered } \\
\text { active in laboratory } \\
\text { - Most of the students of class P03PDG less } \\
\text { skilled in managing the data using an excel } \\
\text { spread sheet }\end{array}$ & \\
\hline 3 & $\begin{array}{l}\text { Background } \\
\text { and Objectives }\end{array}$ & $\begin{array}{l}\text { - Most of the contents are plagiarized } \\
\text { - Background is less relevant to the purpose }\end{array}$ & $\begin{array}{l}\text { By copying from } \\
\text { the internet }\end{array}$ \\
\hline 4 & $\begin{array}{l}\text { Materials and } \\
\text { Research } \\
\text { Procedures }\end{array}$ & $\begin{array}{l}\text { - Materials and equipment used is not fitted } \\
\text { with photographs } \\
\text { - Description of research procedures was } \\
\text { unclear and difficult to follow, lack of } \\
\text { support for photos and description of } \\
\text { activities } \\
\text { - Photos displayed are less clear and less } \\
\text { relevant }\end{array}$ & $\begin{array}{l}\text { Students are less } \\
\text { skilled in creating } \\
\text { tables, adding } \\
\text { photos }\end{array}$ \\
\hline 5 & $\begin{array}{l}\text { Results \& } \\
\text { Explanations }\end{array}$ & $\begin{array}{l}\text { - Data and information: presented only in } \\
\text { the form of tables, poorly supported with } \\
\text { graphics or photographs } \\
\text { - Explanation of results not in line with the } \\
\text { results, since most were plagiarism, not the } \\
\text { result of our own thoughts }\end{array}$ & $\begin{array}{l}\text { Discussion mostly } \\
\text { plagiarism }\end{array}$ \\
\hline 6 & Conclusion & $\begin{array}{l}\text { - Less relevant to the background and } \\
\text { purpose } \\
\text { - Repetition of writing results } \\
\text { - Too long and copied from the results }\end{array}$ & $\begin{array}{l}\text { Most are the result } \\
\text { of plagiarism }\end{array}$ \\
\hline 7 & References & - Less relevant references and not up to date & \\
\hline 8 & Attachment & - Some of the data attached is not original & \\
\hline
\end{tabular}

The students were then advised to revise the data and paper draft according to assignment manual. They were also guided how to prepare introduction, description of research procedures, table and figure construction, presentation of data in various diagram and figure forms, outlines of discussion and conclusion. The students were remained that dishonesty and laziness are the main factors causing the fraud in the writing of scientific papers. Having given the advises and suggestions for improvement, most students made significant improvement in data presentation dan paper writing. This shows that students readily receive advice and are willing to make revision properly. Most students, especially from the P03PDG class, admitted that they have very rarely received guidance from lecturer working in laboratory and in writing scientific assignments. According to Marin [8] giving students the responsibility to design and implement a lesson plan can be viewed as a way to empower students to take control of their own learning process, letting them experience not only the students' perspective about the teaching process, but also the teacher's perspective. The world of industry requires work competencies such as teamwork, creativity, discipline, honesty, commitment, responsibility, 
confidence, ethics, manners, communication, leadership and entrepreneurship [9]. According to Ghose [10] experiential learning can help a student develop a positive attitude towards life, encourage acceptance of responsibility, promote community involvement, develop power of thought and help them understand their strengths and weaknesses in the real world context, thereby inspiring personal growth through the development of global competencies.

\subsection{Grade Achievement}

The assignment as EL model was expected to have a positive impact on the student grade through improving attitudes and behavior. As shown in Table 2, the average mid exam scores achieved was in general very poor, ranging between 35 and 50 . The figures show that the real ability students in understanding the course material was still very limited. The structured assignment had no significant impact on the improvement of exam scores. As shown in Table 3 , the average grade of the P03PDG grade students only increased by about 4 points, from 35 (the average class score) to 39 (mean score of the students taking part in the assignment). At the P01PYK class, mid exam scores only increased by one point, whereas the P02PYK class has the lowest average scores of 34.8. The average final grade of students was increased to 54 to 66 after being combined with the assignment points. In general, the impact of assignment as EL mode on the grade achievement was found nonsignificant, because the student final grade ranged only between $\mathrm{C}$ and $\mathrm{B}^{-}$.

Different results reported by Khalil [11) who found that that implementation of EL model in the Feed Quality Control subject improved the student final grade. The present did not support the argument proposed by Rotreguez and Morant [12] who mentioned that fostering experiential learning strategies favors the students' understanding of theoretical concepts and leads to the attain-ment of superior performance. According to Nooghabi et al. [13] the main challenges of the experiential learning of the practical courses including insufficient educational spaces and equipment, less experienced instructors and technicians, not paying attention to parallel and additional experiences and insufficient class management by the instructors and technicians. These results suggested that there is a need for scaffolding reflection for learning through experience as a process of layered learning interventions designed to encourage students to build their understanding, confidence, skill, and agency as they move into, through, and out of learning experiences that are set outside the formal academic setting. Thus, it is advisable for faculty members to align their skills and course requirements to teach students these skills in tangible ways.

\section{Conclusion}

It was concluded that the limited experience in performing assignment lead the students taking courses of Feed Industry Management encountering difficulties in the preparation of scientific papers. The application of the Experiential Learning model in the form of assignments might enhance soft skills. The assignment that is preceded by field experience in a laboratory was able to encourage students to be more honest, disciplined, obedient, and serious in task execution. However, the application of this EL model has not been able significantly to improve student grade achievement. 


\section{Acknowledgement,}

This research project entitled "Penerapan Model Experiental Learning Pada Mata Kuliah PTK 257. Manajemen Industri Pakan Untuk Pembinaan Softskill Mahasiswa" (Contract No: 024/UN.16.18/PT.01.03/2019), financially supported by the Andalas University, Ministry of Research, Technology, and Higher Education of the Republic of Indonesia.

\section{References}

[1] Widarto, Pardjono dan N. Widodo: Pengembangan model pembelajaran soft skills dan hard skills untuk siswa SMK. (http://lppmp.uny.ac.id/sites/)(2009)

[2] Baki A, M. A. Yahaya, S.H. Hamzah, C.M. Isa, R.M. Sem, R.A. Rahim, A.H. Hassan and S. A Rahim: Improvement of Students' Soft-Skills Through University-Industry Collaborations. Proc. of the 7th WSEAS International Conference on EDUCATION and EDUCATIONAL TECHNOLOGY (EDU'08) (2008)

[3] Katula, R. A., and E. Threnhauser: Experiential education in the undergraduate curriculum. Communication Education, 48(3): 238 (1999)

[4] Khalil: Penerapan model Experiental learning dalam kurikulum pendidikan ilmu Peternakan. Prosiding Seminar Nasional Pendidikan Tinggi LP3M Unand, 6-7Agustus 2015. Padang (2015)

[5] Rayfield, J: An Assesment of Recruitment and Training Practices of the National FFA Livestock Career Development Event. PhD Dissertation. The Graduate Faculty of Texas Tech University (2006)

[6] Conrad, D. and D. Hedin: National assessment of experiential education: A final report. Minneapolis: Minnesota University, Center for Youth Development and Research. (ERIC Document Reproduction Service No. ED 233 765) (1981)

[7] Smith, M.K: 'David A. Kolb on experiential learning', The encyclopedia of informal education, Retrieved June 23, 2015, from http://www.infed.org/b-explrn.htm. (2001)

[8] Marin, E: Experiential learning: empowering students to take control of their learning by engaging them in an interactive course simulation environment. Procedia - Social and Behavioral Sciences 180 ( 2015$) 854-859$ (2015)

[9] Sembiring, L.S, Y. Maputra and Afrinaldi: Developing cooperation skill (soft skills) through implementation of cooperative learning method and experiential learning in psychology entrepreneurship course. Scientific J. of PPI-UKM. 2 (7):296-299 (2015)

[10] Ghose, N: Enhancing global competitiveness through experiential learning: insights into successful programming. American J of Business Education 3(7):1-4 (2010)

[11] Khalil: Penerapan model Experiental Learning pada mata kuliah PTK 027. Pengawasan Mutu Pakan. Prosiding Seminar Nasional Pengembangan Pendidikan Tinggi Ke III, LP3M Unand, 26 Oktober 2017. Padang. Hal: 191-206 (2017)

[12] Rodríguez, A.L.L and G.A Morant: Promoting innovative experiential learning practices to improve academic performance: Empirical evidence from a Spanish Business School. J. of Innovation \& Knowledge 4: 97-103 (2019)

[13] Nooghabi, S.N, H.Iravani, and H.S.Fami. A study on present challenges on experiential learning of university students (University of Tehran, The Colleges of Agriculture and Natural Resources, Iran). Procedia Social and Behavioral Sciences 15 (2011) 3522-3530 